\title{
Efficacy and Safety of New and Emerging Drugs for COVID-19: Favipiravir and Dexamethasone
}

\author{
Shivani Sood ${ }^{1}$. Gurpreet Kaur Bhatia ${ }^{2}$. Prachi Seth ${ }^{1} \cdot$ Pawan Kumar $^{3}$ - Jagjit Kaur ${ }^{4}$ • Vidisha Gupta ${ }^{5}$. \\ Sandeep Punia ${ }^{6} \cdot$ Hardeep Singh Tuli ${ }^{7}$ (D)
}

Accepted: 2 February 2021 / Published online: 18 February 2021

(C) The Author(s), under exclusive licence to Springer Nature Switzerland AG part of Springer Nature 2021

\begin{abstract}
Purpose of Review The widespread respiratory disease of virus known as severe acute respiratory syndrome-coronavirus 2019 (SAR-CoV-2) had infected more than 200 countries and caused pandemic and havoc in the world.

Recent Findings The genome of the virus was sequenced rapidly to study its mechanism, epidemiology, drugs, and vaccines. Many drugs and vaccines are being studied by researchers to treat and prevent the SARS-CoV-2. Favipiravir and dexamethasone are repurposed drugs which showed therapeutic potential and pharmaceutical efficacy against SARS-CoV-2.

Summary The review describes the path of favipiravir and dexamethasone from chemistry to mechanisms of action to combat SARS-CoV-2. In addition, the potential side effects are also summarized to study their potential to control corona virus 2019.
\end{abstract}

Keywords Severe acute respiratory syndrome $\cdot$ Coronavirus $2019 \cdot$ Epidemiology $\cdot$ Favipiravir $\cdot$ Dexamethasone

\section{Introduction}

For more than 50 years, the respiratory viral infection SARS$\mathrm{CoV}$ had caused several deaths in the world. In December 2019 , the coronavirus SARS-CoV-19 spread by bats in

This article is part of the Topical Collection on Clinical Pharmacology

Hardeep Singh Tuli

hardeep.biotech@gmail.com

1 Department of Biotechnology, Mukand Lal National College, Yamuna Nagar, India

2 Department of Physics, Maharishi Markandeshwar (Deemed to be University), Mullana, Ambala 133207, India

3 Institute of Plant Sciences, Agricultural Research Organisation (ARO), 7505101 Rishon LeZion, Israel

4 Graduate School of Biomedical Engineering, ARC Centre of Excellence in Nanoscale Biophotonics (CNBP), Faculty of Engineering, The University of New South Wales, Sydney 2052, Australia

5 Department of Zoology, Mukand Lal National College, Yamuna Nagar, India

6 Department of Biotechnology, Multani Mal Modi College, Patiala, India

7 Department of Biotechnology, Maharishi Markandeshwar (Deemed to be University), Mullana, Ambala 133207, India
Wuhan city of China, which later on in March 2020 caused havoc situation worldwide. This virus has the largest RNA genome, spike-like projections on its body surface (Fig. 1), and high replication, mutation, and recombination rate [1]. The respiratory droplets of an infected person and food which is contaminated by respiratory droplets are the major causes of infection in an uninfected person causing damage to the lungs. Cytokines are also responsible for damage to the lungs and required the $\mathrm{T}$ cells, i.e., thymus cells and specific antibodies to activate and fight against this coronavirus. Till now, only experimental and hypothetical treatments with many repurposed drugs which include antibiotics, antiviral, anti-parasitic, anti-inflammatory, corticosteroids, and antimalarial with their combinations have been studied and tried as competent therapy in the cure and treatment for the SARS-CoV-19 with the purpose of low cost and an immediate effect $[2,3]$.

Antiviral medicines are used for the cure of viral infections and most of the viral infections are resolved spontaneously in many individuals. The antiviral treatment stops the replication of the virus which leads to a decrease in the infection process, its symptoms, and reduce the duration of the disease. The corticosteroids can also be considered as one of the potent therapeutic drug in Covid-19 treatment. A number of corticosteroid compounds have been synthesized and proved to be a life-saving drug in this pandemic. Furthermore, these drugs were also studied in combination with other drugs. 


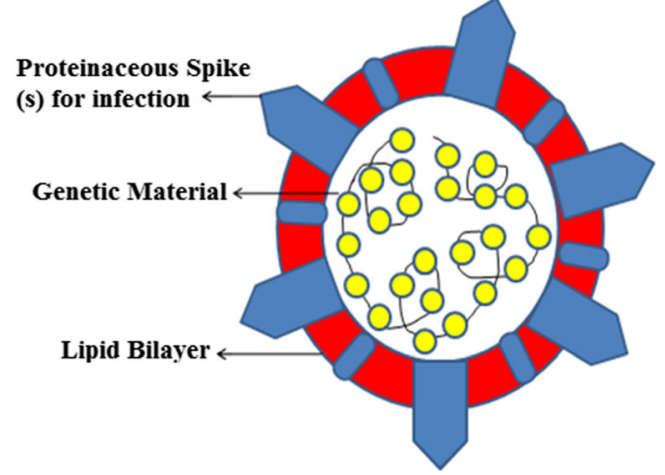

Fig. 1 Structure of coronavirus with spikes for infection, ribonucleic acid (RNA) as genetic material, and lipid bilayer

Therefore, in this paper, we have given an outline on antiviral drug named as favipiravir [4] and a corticosteroid drug, dexamethasone [5], as competitive inhibitors in RNA viral infection. This review thoroughly studied and searched the NCBI database (https://pubmed.ncbi.nlm.nih.gov/), much accessible literature, and related websites till date, to cover chemistry, mechanistic mode of action, usage in clinical trials, and side effects of above-mentioned drugs.

\section{Chemistry of Favipiravir and Dexamethasone}

The novel anti-viral favipiravir discovered by Japanese company Toyama Chemical Co., Ltd., whereas anti-inflammatory dexamethasone licensed by EU EMA and INN:US to inhibit RNA viruses and respiratory infection in SARS-CoV. The drug favipiravir was first permitted in Japan (year 2014) and further carried out to use in 2019-2020 pandemic in Wuhan against SARS-CoV-2. On the other hand, dexamethasone was recommended by Oxford University for the infected patients which were on the ventilator [6-9]. With an increase in the pandemic of Covid-19, many countries like Europe, Italy, Turkey, Egypt, Bangladesh, Ukraine, Japan, Uzbekistan, Russia, Moldova, Kazakhstan, Dubai, and Saudi Arabia got approval for the use of drug favipiravir against SARS-CoV-2. In June 2020, the DCGI also approved and recommended its use in India for mild viral symptoms $[4,10]$. Table 1 contains the physiochemical properties of favipiravir and dexamethasone which are retrieved from PubChem [11]. The major function of favipiravir in coronavirus-2019 treatment is known to inhibit RNAdependent RNA polymerase (RdRP) viral infection to interrupt the incorporation process of nucleotide [12-14] and dexamethasone inhibits the cytokine growth or storms along with hyperinflammation [15]

\section{Mode of Action of Favipiravir and Dexamethasone in SARS-CoV-19}

Since drug development for the treatment of SARS-CoV-19 is in progress, the researchers are looking for the previously approved and unapproved drugs to fight with SARS and MERS [16]. Therefore, it is extremely essential to understand the receptors binding angiotensin converting enzyme 2 (ACE2) of host epithelial cells, origin of the virus, and the targeted organs spectrum to design promising anti-COVID therapy $[17,18]$. Various nucleoside/nucleotides analogs such as favipiravir, ribavirin, and remdesivir block the synthesis of viral RNA by targeting the RNA-dependent RNA polymerase (RdRp) [19]. Therefore, these drugs have been considered to have potential against SARS-CoV-19 [20]. The guanine ana$\log$, favipiravir, an approved drug for the treatment of influenza, also possesses the anti-viral potential against yellow fever, enterovirus, Ebola, norovirus, and chikungunya [19, 21]. It is also known to block the RNA synthesis of SARS$\mathrm{CoV}-19$ at a concentration of EC50 $=61.88 \mu \mathrm{M}$ in Vero E6

Table 1 Physiochemical properties of favipiravir and dexamethasone

\begin{tabular}{|l|l|l|}
\hline $\begin{array}{l}\text { Physiochemical } \\
\text { Properties }\end{array}$ & Favipiravir & Dexamethasone \\
\hline Other Names & $\begin{array}{l}\text { 6-fluoro-3-hydroxy-2- } \\
\text { pyrazinecarboxamide, Avigan, T-705 cpd }\end{array}$ & $\begin{array}{l}\text { Decadron, Maxidex, } \\
\text { Dexamethazone }\end{array}$ \\
\hline Molecular Formula & C5H4FN3O2 & C22H29FO5 \\
\hline Molecular Weight & $157.1 \mathrm{~g} / \mathrm{mol}$ & $392.5 \mathrm{~g} / \mathrm{mol}$ \\
\hline Structure & \multicolumn{1}{|c|}{}
\end{tabular}


cells. However, further studies need to be carried out to demonstrate its anti-viral activity in vivo [20].

It is known that favipiravir competes with the purine nucleosides and its activity may be attenuated in the presence of purine bases or nucleosides. Once incorporated into the cells, favipiravir is activated and products like favipiravir ribofuranosyl-5'-monophosphate (favipiravir-RMP), favipiravir ribofuranose (favipiravir-R), and favipiravir ribofuranosyl-5'-triphosphate (favipiravir-RTP) are generated [22] (Fig. 2). However, only favipiravir-RTP can inhibit the RNA polymerase activity of the viral genome [13]. Although the actual mechanism behind the favipiravir-RTP-RdRp interaction is unknown, it is hypothesized that it blocks the viral transcription and replication by binding to the conserved polymerase chains or by misincorporation in the nascent RNA of the virus [23].

Another drug that is gaining name in the list of anti-SARSCoV-19 drugs is dexamethasone. Dexamethasone, also known as Decadron, is a glucocorticosteriod similar to the one produced by adrenal glands in human body. It is considered an economically cheap option to save lives immediately across the globe after a study in which death rate was reduced by one-fifth in patients receiving oxygen therapy and by onethird in patients on ventilators after they were given dexamethasone [15]. The mechanism behind the virucidal effects of dexamethasone is still unknown; however, it is considered that dexamethasone binds to the cortisol to enhance the production of anti-inflammatory proteins, which further suppress the release of pro-inflammatory cytokines responsible for lung damage [24•]. Further investigations need to be done to better study the mechanism of action behind the virucidal effects of dexamethasone.

\section{Ongoing Clinical Studies and Guidelines}

The increase in the pandemic coronavirus or Covid-19 across the world proved the amount of antiviral and repurposed drugs which accelerated into treatment after conducting the clinical trials. The antiviral drugs such as favipiravir and dexamethasone have shown to be effective against SARS-CoV-2 [25]. Therefore, these therapeutic drugs used as an experimental agent in the ongoing clinical trials to find out the best treatment for Covid-19 patients in Japan and China. Favipiravir shows promising efficacy against SARS-CoV-2 in Vero E6 cells with effective concentration (EC50) of $61.88 \mu \mathrm{M}$. It is considered to be safe and effective treatment for Covid-19 patients [26]. In China, a control trial (ChiCTR200030254) has shown the excellent recovery rate (71.43\%) of Covid-19 patients with less duration of fever and cough relief time, when treated with favipiravir as compared with umifenovir (55.86\%) [27•]. In Japan and China, there were about eight undergoing clinical trials (JPRNjR C Ts 031190226 , JPR NjR C Ts 041190120 , ChiCTR2000029600) of favipiravir to test its potential, efficiency, and efficacy against the Covid-19 disease. Favipiravir showed faster recovery rate of Covid-19 patients in clinical trials as compared with lopinavir/ritonavir [28]. Nowadays, in clinical trials, favipiravir is also giving in combination with other therapeutic agents such as oseltamivir and chloroquine [29••]. On the other hand, dexamethasone drug is widely utilized in the

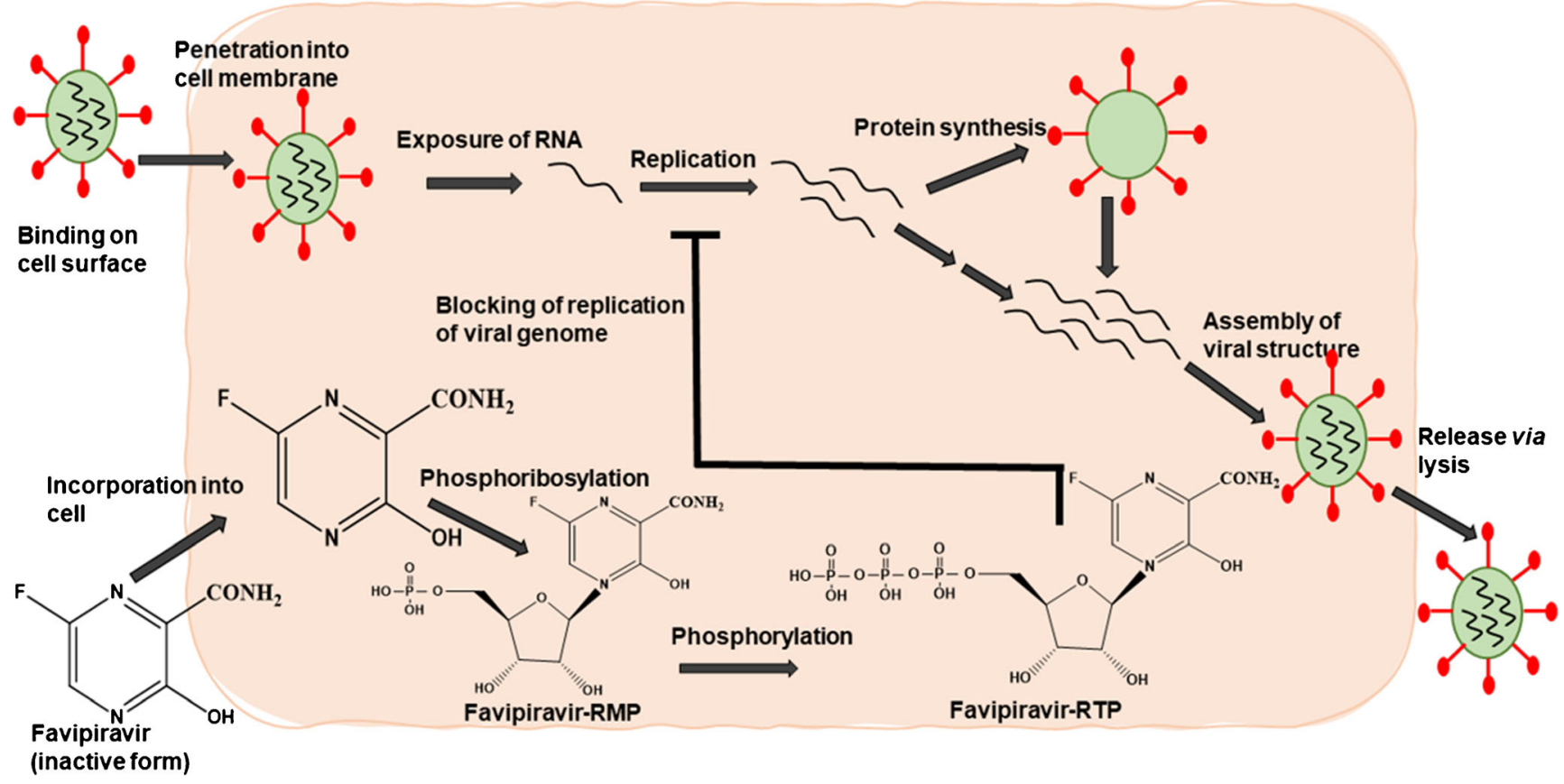

Fig. 2 Schematic representation of mode of action of favipiravir. Favipiravir is incorporated into the host cell where it undergoes phosphorylation to form favipiravir-RTP which blocks the replication of viral genome 
treatment of allergies, asthma, autoimmune diseases (lupus), and rheumatoid arthritis [26, 30, 31]. Nowadays, this drug is more popular for the treatment of Covid-19 disease because of its utility to reduce the mortality rate and to increase treatment efficiency. The phase II/III ongoing clinical trials show the promising results of dexamethasone against the SARS-CoV-2 [15]. This drug reduced the mortality rate by $1 / 5$ th in the Covid-19 patients that required ventilation support [32••]. It reduces the cytokine storm and help in early recovery of Covid-19 patients. In 2020, the Recovery Collaborative Group investigated that dexamethasone was more prominent in treating serious ill Covid-19 patients with high recovery rate. However, with milder infection cases, there are less beneficial effects [15]. Maskin et al. [33••] explored the effectiveness and safety of high-dose dexamethasone treatment for acute respiratory distress syndrome. Recently, Tomazini et al. [34••] have performed one randomized clinical trial of intravenous dexamethasone that included 299 patients, with the aim to check the number of ventilator-free days among patients with Covid-19-associated ARDS (acute respiratory distress syndrome). This study found the promising results in terms of increased ventilator-free days (28 days). As per our latest knowledge, 14 clinical trials were planned to check the efficiency and efficacy of dexamethasone drug around the world that would likely to be complete in the end of 2020 .

\section{Usage and Side Effects of Favipiravir and Dexamethasone}

\section{Usage}

Favipiravir drug is a prescribed medication with the recommended oral dose of $1800 \mathrm{mg}$ twice a day for adults $(\geq 16)$. On day 1 followed by $800 \mathrm{mg}$ from day 2 twice daily up to 14 days [28], whereas dexamethasone drug was recommended orally or intravenous (IV) dose of $6 \mathrm{mg}$ daily up to 10 days but only in hospitalized patients who need supplemental oxygen or in patients who are mechanically ventilated days [35].

\section{Side Effects}

The side effects of favipiravir cause teratogenicity and embryotoxicity. Therefore, it should not be administered in women who are either pregnant or suspected to be pregnant. Prolongation of corrected QT interval was reported in an Ebola virus patient when treated with high doses of favipiravir. Other side effects of favipiravir include gastrointestinal disorders such as vomiting, diarrhea, nausea, duodenal ulcer, and abdominal discomfort [36]. The dexamethasone drug is associated with increased number of deaths in cancer patients diagnosed with Covid-19. One of the most neglected and less familiar complications of using dexamethasone steroid is the strongyloides hyper-infection [37]. Other side effects include fluid retention, elevation in blood sugar levels, weight gain, and long-term usage that can lead to some serious complications. Sudden suspension or stoppage of steroids in steroid-dependent people may cause adrenal insufficiency [38].

\section{Conclusion}

The present pandemic Covid-19 is the furthermost challenge to the scientist as there is no treatment and vaccine till now. Across the globe, medical researchers and scientists are working vigorously for the development of anti-Covid drugs and their therapy as soon as possible. Many drugs have shown hopeful results but still larger trials are to be needed to show the remarkable results. The drugs like favipiravir and dexamethasone showed effective results in SARS-CoV-2 or Covid-19 treatment. Even though there is more studies required to prove that patients who are treated with favipiravir and dexamethasone can recover faster, and both the drugs can extensively enhance the conditions of patients with mild fever and cough as side effects. Therefore, new clinical trials should be carried out for the prospective use of dexamethasone and favipiravir in coronavirus treatment.

\section{Declarations}

Human and Animal Rights and Informed Consent This article does not contain any studies with human or animal subjects performed by any of the authors.

Conflict of Interest Authors declare no potential conflict of interest.

\section{References}

Papers of particular interest, published recently, have been highlighted as:

- Of importance

-• Of major importance

1. Sood S, Aggarwal V, Aggarwal D, Upadhyay SK, Sak K, Tuli HS, et al. COVID-19 pandemic: from molecular biology, pathogenesis, detection, and treatment to global societal impact. Curr Pharmacol Rep. 2020;27:1-6. https://doi.org/10.1007/s40495-020-00229-2.

2. Munir MA, Kuganda H, Basry A. The efficacy and safety of antivirus drugs for COVID-19: a systematic review. Sys Rev Pharm. 2020;11:162-6. https://doi.org/10.31838/srp.2020.7.26.

3. Naveed M, Uddin S, Abdullah KS, Ishaq SE, Ahmad T. Various evidence-based hypothetical and experimental treatment approaches and their effectiveness against COVID-19 worldwide: a comprehensive literature review. Eurasian J Med Oncol. 2020;4: 265-85. https://doi.org/10.14744/ejmo.2020.52538.

4. Agrawal U, Raju R, Udwadia ZF. Favipiravir: a new and emerging antiviral option in COVID-19. Med J Armed Forces India. 2020;76: 370-6. https://doi.org/10.1016/j.mjafi.2020.08.004. 
5. Theoharides TC, Conti P. Dexamethasone for COVID-19? Not so fast. J Biol Regul Homeost Agents. 2020;34:3. https://doi.org/10. 23812/20-EDITORIAL 1-5.

6. Naesens L, Guddat LW, Keough DT, van Kuilenburg AB, Meijer J, Voorde JV, et al. Role of human hypoxanthine guanine phosphoribosyltransferase in activation of the antiviral agent T-705 (favipiravir). Mol Pharmacol. 2013;84:615-29. https://doi. org $/ 10.1124 / \mathrm{mol} .113 .087247$.

7. Guo Q, Xu M, Guo S, Zhu F, Xie Y, Shen J. The complete synthesis of favipiravir from 2-aminopyrazine. Chem Pap. 2019;73:104351. https://doi.org/10.1007/s11696-018-0654-9.

8. Sangawa H, Komeno T, Nishikawa H, Yoshida A, Takahashi K, Nomura N, et al. Mechanism of action of T-705 ribosyl triphosphate against influenza virus RNA polymerase. Antimicrob Agents Chemother. 2013;57:5202-8. https://doi.org/10.1128/aac.0064913.

9. Whelan R, Apfel CC. Pharmacology of postoperative nausea and vomiting. In: Pharmacology and Physiology for Anesthesia. 2013, p. 503-22. https://doi.org/10.1016/B978-1-4377-1679-5.00029-6.

10. Glenmark gets DCGI nod for favipiravir use in Covid-19. Hindu Business Line. https://www.thehindubusinessline.com/companies/ glenmark-gets-dcgi-nod-for-favipiravir-use-in-covid-19/ article31871629.ece. Accessed 19 June 2020.

11. Kim S, Chen J, Cheng T, Gindulyte A, He J, He S, et al. PubChem 2019 update: improved access to chemical data. Nucleic Acids Res. 2019;47:D1102-9. https://doi.org/10.1093/nar/gky1033.

12. Furuta Y, Takahashi K, Shiraki K, Sakamoto K, Smee DF, Barnard DL, et al. T-705 (favipiravir) and related compounds: novel broadspectrum inhibitors of RNA viral infections. Antivir Res. 2009;82: 95-102. https://doi.org/10.1016/j.antiviral.2009.02.198.

13. Furuta Y, Gowen BB, Takahashi K, Shiraki K, Smee DF, Barnard DL. Favipiravir (T-705), a novel viral RNA polymerase inhibitor. Antivir Res. 2013;100:446-54. https://doi.org/10.1016/j.antiviral. 2013.09.015.

14. Jin Z, Tucker K, Lin X, Kao CC, Shaw K, Tan H, et al. Biochemical evaluation of the inhibition properties of favipiravir and 2'-C-methyl-cytidine triphosphates against human and mouse norovirus RNA polymerases. Antimicrob Agents Chemother. 2015;59:7504-16. https://doi.org/10.1128/aac.01391-15.

15. Horby P, Lim WS, Emberson JR,Mafham M,Bell JL,Linsell L, Staplin N, et al. Dexamethasone in hospitalized patients with Covid-19 - preliminary report. N Eng1 J Med. 2020: NEJMoa2021436. https://doi.org/10.1056/NEJMoa2021436.

16. Kupferschmidt K, Cohen J. Science News. WHO launches global megatrial of the four most promising coronavirus treatments. 2020. https://www.sciencemag.org/news/2020/03/who-launches-globalmegatrial-four-most-promising-coronavirus-treatments. Accessed 26 Mar 2020.

17. Malik YS, Sircar S, Bhat S, Sharun K, Dhama K, Dadar M, et al. Emerging novel coronavirus (2019-nCoV) - current scenario, evolutionary perspective based on genome analysis and recent developments. Vet Q. 2020;40:68-76. https://doi.org/10.1080/ 01652176.2020 .1727993$.

18. Debnath SK, Srivastava R, Omri A. Emerging therapeutics for the management of COVID 19. Exp Opin Emerg Drugs. 2020;25:33751. https://doi.org/10.1080/14728214.2020.1810663.

19. Li G, De Clercq E. Therapeutic options for the 2019 novel coronavirus (2019-nCoV). Nat Rev Drug Discov. 2020;19:149-50. https://doi.org/10.1038/d41573-020-00016-0.

20. Artese A, Svicher V, Costa G, Salpini R, Di Maio VC, Alkhatib M, et al. Current status of antivirals and druggable targets of SARS CoV-2 and other human pathogenic coronaviruses. Drug Resist Updat. 2020;26:100721.

21. Oestereich L, Lüdtke A, Wurr S, Rieger T, Muñoz-Fontela C, Günther S. Successful treatment of advanced Ebola virus infection with T-705 (favipiravir) in a small animal model. Antivir Res. 2014;105:17-21.

22. Furuta Y, Takahashi K, Kuno-Maekawa M, Sangawa H, Uehara S, Kozaki K, et al. Mechanism of action of T-705 against influenza virus. Antimicrob Agents Chemother. 2005;49:981-6. https://doi. org/10.1128/AAC.49.3.981-986.2005.

23. Furuta Y, Komeno T, Nakamura T. Favipiravir (T-705), a broad spectrum inhibitor of viral RNA polymerase. Proc Jpn Acad Ser B Phys Biol Sci. 2017;93:449-63. https://doi.org/10.2183/pjab.93. 027.

24. Fadaka AO, Sibuyi NR, Madiehe AM, Meyer M. Computational insight of dexamethasone against potential targets of SARS-CoV-2. J Biomol Struct Dyn. 2020;12:1-1. https://doi.org/10.1080/ $07391102.2020 .1819880 \mathrm{~s}$. Study describes the role of computational tools to explore targets of dexamethasone against COVID-19.

25. Wu R, Wang L, Kuo HC, Shannar A, Peter R, Chou PJ, et al. An update on current therapeutic drugs treating COVID-19. Curr Pharmacol Rep. 2020;6:1-15. https://doi.org/10.1007/s40495020-00216-7.

26. Wang M, Cao R, Zhang L, Yang X, Liu J, Xu M, et al. Remdesivir and chloroquine effectively inhibit the recently emerged novel coronavirus (2019-nCoV) in vitro. Cell Res. 2020;30:269-71. https:// doi.org/10.1038/s41422-020-0282-0.

27. Chen C, Huang J, Cheng Z, Wu J, Chen S, Zhang Y, Chen B, Lu M, Luo Y, Zhang J, Yin P. Favipiravir versus arbidol for COVID-19: a randomized clinical trial. MedRxiv. 2020. https://doi.org/10.1101/ 2020.03.17.20037432. A very useful comaparitive analysis of favipiravir and arbidol against COVID-19

28. Cai Q, Yang M, Liu D, Chen J, Shu D, Xia J et al. Experimental treatment with favipiravir for COVID-19: an open-label control study. Engineering. Engineering (Beijing).2020.https://doi.org/10. 1016/j.eng.2020.03.007.

29.• ClinicalTrials.gov. Various combination of protease inhibitors, oseltamivir, favipiravir, and chloroquine for treatment of COVID19: a randomized control trial (THDMS-COVID19). NCT04303299.Bethesda (MD): National Library of Medicine (US); Accessed on 12 March 2020. The investigation provides an insight into a combinatorial approch for COVID-19 treatment.

30. Elkharwili DA, Ibrahim OM, Elazab GA, Elrifaey SM. Two regimens of dexamethasone versus prednisolone for acute exacerbations in asthmatic Egyptian children. Eur J Hosp Pharm. 2020;27: 151-6. https://doi.org/10.1136/ejhpharm-2018-001707.

31. Shrestha BR, Maharjan SK, Shrestha S, Gautam B, Thapa C, Thapa PB, et al. Comparative study between tramadol and dexamethasone as an admixture to bupivacaine in supraclavicular brachial plexus block. JNMA J Nepal Med Assoc. 2007;46:158-64.

32.•V Villar J, Ferrando C, Martínez D, Ambrós A, Muñoz T, Soler JA, et al. Dexamethasone treatment for the acute respiratory distress syndrome: a multicentre, randomised controlled trial. Lancet Respir Med. 2020;8:267-76. https://doi.org/10.1016/S22132600(19)30417-5. A promissing clinical trial for COVID-19 therapy using Dexamethasone.

33.• Maskin LP, Olarte GL, Palizas F, Velo AE, Lurbet MF, Bonelli I, et al. High dose dexamethasone treatment for acute respiratory distress syndrome secondary to COVID-19: a structured summary of a study protocol for a randomised controlled trial. Trials. 2020;21:13. https://doi.org/10.1186/s13063-020-04646-y. This investigation provides an insight into dexamethasone mediated therapy for COVID-19 patients.

34.• Tomazini BM, Maia IS, Cavalcanti AB, Berwanger O, Rosa RG, Veiga VC, et al. Effect of dexamethasone on days alive and ventilator-free in patients with moderate or severe acute respiratory distress syndrome and COVID-19: the CoDEX randomized clinical trial. Jama. 2020;324:1-11. https://doi.org/10.1001/jama.2020. 
17021. Study described the utility of dexamethasone to increase the surviual rate of COVID-19 patients.

35. Chinello P, Petrosillo N, Pittalis S, Biava G, Ippolito G, Nicastri E, et al. QTc interval prolongation during favipiravir therapy in an Ebola virus-infected patient. PLoS Negl Trop Dis. 2017;11: e0006034. https://doi.org/10.1371/journal.pntd.0006034.

36. Czock D, Keller F, Rasche FM, Haussler U. Pharmacokinetics and pharmacodynamics of systemically administered glucocorticoids. Clin Pharmacokinet. 2005;44:61-98. https://doi.org/10.2165/ 00003088-200544010-00003.
37. Krolewiecki A, Nutman TB. Strongyloidiasis: a neglected tropical disease. Infect Dis Clin. 2019;33:135-51. https://doi.org/10.1016/j. idc.2018.10.006.

38. Lim MA, Pranata R. The insidious threat of jamu and unregulated traditional medicines in the COVID-19 era. Diabetes Metab Syndr. 2020;14:895-6. https://doi.org/10.1016/j.dsx.2020.06.022 Epub 2020 Jun 12.

Publisher's Note Springer Nature remains neutral with regard to jurisdictional claims in published maps and institutional affiliations. 